\title{
Research on Affective Teaching Strategy in China's College English Classroom
}

\author{
Qiang Zhang ${ }^{1}$ \\ ${ }^{1}$ School of Foreign Languages, Shandong Jiaotong University, Jinan 250023, China \\ Correspondence: Qiang Zhang, 5001 Haitang Road, Jinan, Shaodong Province, 250023, China. Tel: \\ 86-186-6017-6618. E-mail: 170983040@qq.com
}

Received: June 10, 2014

Accepted: June 19, 2014

Online Published: June 20, 2014

doi:10.5430/ijhe.v3n3p39

URL: http://dx.doi.org/10.5430/ijhe.v3n3p39

\begin{abstract}
Affective teaching plays an increasing significant role in the teaching process; it not only attaches great importance to the teaching of knowledge and skills, but also pays specific attention to students' attitude and emotional needs in the process of teaching, so as to promote students' overall development as well as improving their comprehensive qualities. In this paper, the author first put forward the current problems of English teaching in China, and then introduced some relevant studies of affective teaching. Finally the author tries to explain the strategies of applying emotional factors to the college English classroom from both the students' and the teachers' perspective.
\end{abstract}

Keywords: Affective teaching, Emotional factors, College English classroom, Motivation

\section{Introduction}

Currently, the discussion on college English teaching in China mainly focuses on the quality of teachers, teaching facilities, teaching content, teaching environment, curriculum provision, teaching methods, etc, and the teaching method is being discussed as the focal point. The teaching effect is decided by the teaching approach to a large extent. With the deepening of teaching reform in China, people become more aware of the importance of the application of emotional factors in teaching and the necessity of affective teaching. English teaching in universities and colleges should also keep up with the pace of the trend of affective teaching. Affective teaching focuses not only on the cognitive factors in teaching, but also the emotional factors in teaching. It requires the teachers to combine the cognitive and emotional factors together organically in the process of teaching. Affective teaching can help to create a harmonious classroom atmosphere, and establish a good relationship between teachers and students, so as to promote the students' interest in learning and improve the effect of classroom teaching. Therefore, the application of emotional factors to the classroom teaching should be a very important question in China's college English teaching reform.

The process of English teaching can be defined as a process of "cognition plus emotion". However, for a long time, English teaching in Chinese universities has neglected the emotional factors. The English classroom teaching in universities still operates on the principle of "teachers as the center" and teachers still account for most of the teaching time. The only link between teachers and students is the knowledge; there is scarce emotional communication in the classroom. Teaching has become a one-way output of knowledge, but not a mutual interaction between teachers and students. Students' participation in English classroom is not optimistic: they lack the motivation of learning English and even skip school. This kind of learning atmosphere has also weakened the enthusiasm of teachers to a certain extent. Teachers play the role as the knowledge importer and the role model for the students during the teaching process, their behaviors could have a significant effect on the students. Teachers should stimulate the students' enthusiasm for learning by using their own positive emotions so as to lead them to an active and positive way of learning. Thus the teaching effect in English classroom could be gradually promoted.

Tedious classroom atmosphere, students' lack of enthusiasm and self-confidence, the poor relationship between teachers and students, and disturbance of emotion in learning process are the major problems that need to pay close attention to in college English teaching reform. 


\section{Literature Review}

Studies on English affective teaching is discussed mainly on the characteristics of the affective teaching, the problems of English teaching and the application of emotional factors to English teaching. Different conclusions are drawn according to different kind of research.

Liu Runqing (1999) put forward three key factors of language learning: intelligence and language talent, the cognitive style and the personality factors. Underhill proposes that teachers can be divided into three categories: lecturer, teacher and facilitator. Wang Qimin (2003) found that only about $12 \%$ of the students feel confident about their college English learning through the survey, while as high as $88 \%$ of the students are not satisfied with college English teaching, and they lack of a sense of achievement. So the lack of successful experience and the learning effect are closely related.

Wang Xiaoying (2001) thinks that the main negative factor affecting the college English teaching is the emotional disturbance. Emotional disturbance refers to the hindrance of learning foreign languages which is caused by the psychological factors, namely the first hindrance which directly influences the effect of learning foreign languages. Hence teachers should find a way to reduce the hindrance during the teaching process. Yang Lihua, Xie Jinxuan (1996) has conducted a questionnaire survey on the college students' English learning situation and the result indicates that positive emotional factors are not properly applied in college English teaching and learning, on the contrary, negative emotional factors are generally exist in the process of learning English, thus restrains the students' development of English ability.

Liao Hongyan (2005) proposes that the learning motivation, traits of character, learning persistence and other non-intellectual factors play an important role in college students' English learning; therefore, in order to reap good benefits in English teaching, teachers must have a thorough understanding of the students' psychological features and apply all the positive factors to overcome the students' negative attitude toward learning English.

In conclusion, the emotional factor plays an indispensable role in English teaching. In order to promote English learning effect, teachers must first ask students to study English with a kind of emotion, this kind of emotional immersion needs teachers to realize it by personal example as well as verbal instruction.

\section{The Application of Emotional Strategy in College English Teaching}

\subsection{From the Students' Perspective}

\subsubsection{Correcting the Students' Study Attitude}

Compared with the first language acquisition, the process of second language learning is a more complicated mental process; students should first accept it psychologically and put it into practice. Under the international circumstance, English is very important for Chinese students undoubtedly. Learning English well can make the students understand the wonderful culture of other countries and help students communicate with foreign friends with more efficiency. It can also prepare the students a way of stepping into the professional world and help students to acquire more advanced science and technology and so on. These can undoubtedly help students to correct their attitude in learning English."Attitude is everything", this sentence is also suitable for English learning. When the students hold a correct attitude to English learning, they may take a step further toward success.

\subsubsection{Cultivating the Students' Interest in Study}

Interest is the most important psychological factor to determine the effect of English study. Therefore, one of the most important duties for a teacher is to stimulate the students' enthusiasm of learning English. If students don't have any enthusiasm for learning English, they will not be willing to invest time and effort for it, or even hate this course; once the students have great enthusiasm for English, they will act to make the actual efforts to achieve better grades. How to cultivate the students' interest in learning has been the focus of ancient and modern educators. As early as the 1850's, the British famous educator Spencer had put forward the "joyful education" theory; Russian famous educator Wocensky once proposed that: "No interest in learning is to force the students to study; it will kill the enthusiasm of the students' thirst for knowledge." Interest is a result of demand to a certain extent, when students understand the importance of learning English, they will be interested in learning it and make effort to study it well. Interest could directly influence the quality of learning, so the teachers should pay attention to cultivating the students' interest in the teaching process and stimulate the enthusiasm of the students to learn English. English teachers could assign specific activities to stimulate students' learning enthusiasm: first of all, teachers can organize English knowledge contests for students, such as English speech competition, English debating competition, interesting English knowledge competition, classical poetry recitation contest, English drama competition and so on, and the students 
could develop their interest in learning by the form of competition and cooperation; secondly, the English teachers may prepare some English songs, poems, classic movies with Chinese subtitles for the students, in such relaxed atmosphere the students not only could relax themselves but also learn the corresponding knowledge on phonetics and vocabulary; moreover, the teachers should spend more time to learn about students' emotional state and mental state to shorten the psychological distance with the students and help them to eliminate emotional hindrance on the way of learning English.

\subsubsection{Stimulating the Students' Learning Motivation}

Motivation is the internal power of human behaviors. Foreign language educators have proposed that second language learning motivation can be divided into categories: integrative motivation and instrumental motivation, both of the two kinds of motivation have a huge impact on English learning. Integrative motivation refers to the learners' understanding or special interest in the target language community; they want to get close to it or expect to participate in the social life of the community. Instrumental motivation refers to the learners' aim to gain economic benefits or other benefits, such as passing an exam, gaining a scholarship, fulfilling a job, getting promotion, etc. Since the two kinds of motivation could both promote students' English ability, teachers should stimulate the students' integrative motivation and instrumental motivation in the teaching process, encouraging students to develop their English listening, speaking, reading and writing abilities and reserve language knowledge for communicating with others. Meanwhile, the teachers can also use instrumental motivation such as scholarship or a good job as an attraction to stimulate students' English learning motivation.

\subsubsection{Promoting the students' Confidence}

Self-confidence has a significant impact on learners' learning effectiveness, but the fact is that in most Chinese universities, the majority of students have no confidence in their English ability. They are afraid of speaking English for fear that the teachers and other students might laugh at them. Research shows that students who have self-confidence can seize more opportunities to practice and learn so as to improve their listening and speaking skills constantly; students who do not have self-confidence are in short of the learning motivation, often expressing their discouragement, and they might miss a lot of chances to exercise. The inferiority of many college students in English learning is the result of past unsuccessful English learning experiences; therefore the teachers could share their own experiences on how to overcome the inferiority gradually, encouraging students to walk out of the psychological shadow of the past. At the same time, the teachers should teach students to learn how to respect others. Under such a harmonious circumstance, the inferior students would regain confidence and express themselves in English with courage, even when there is an error, the teachers should first give positive comments on their performance and then correct the mistakes. Furthermore, for students whose English ability is quite weak, the teacher may arrange the level of difficulty of the students' homework from simple to complex, giving them more chances of enjoying success. With more successful experiences, the confidence of the students will be promoted.

\subsubsection{Enhancing the Students' Group Cohesion}

The students' emotional motivation not only comes from their own, but also from their living environment and people around. At present, the English teaching in colleges and universities gradually begin to adopt question-based teaching and discussion-based teaching approach; both of the two teaching methods are helpful for inspiring students' enthusiasm to participate in class, causing unavoidable competition. Appropriate competition may arouse the desire of extroverted students to show their talent, while for introverted students, too much competition will make them feel anxious, this kind of emotion makes students lose confidence in English learning, and a sense of distrust may emerge among the students. Competitive learning is necessary, while the author thinks that cooperative learning can create a harmonious class atmosphere. First of all, cooperative learning can ease the anxiety of students, students can feel more relaxed to express themselves in the group communication; Secondly, cooperative learning provides the introverted students more opportunities to perform themselves, in the past they were afraid of speaking English in front of the whole class, but when participating in the group communication their degree of anxiety is significantly decreased; Moreover, cooperative learning can enhance the communication between students and strengthen the emotional exchange between the students and thus strengthen the class cohesion. How to promote the cooperative teaching and enhance the class cohesion? First, the teachers should set up a friendly image among the students. The teacher's role model has a great influence on the students' attitude and can directly affect the performance of students, in such kind of atmosphere, the relationship among students will be more and more harmonious; Second, the teachers should organize the students to exchange their minds and talk about questions regularly, thus to promote the understanding among students and eliminate contradictions and misunderstanding; Third, the teachers should encourage students to participate in the activities jointly. The teacher can give students some tasks that must be 
finished through their joint efforts, such as word solitaire game, English team debate, role playing and so on. Through a series of cooperative learning, the teachers can create a relaxed and happy learning atmosphere for students, thus strengthen the cooperation and cohesion among the students.

\subsubsection{Reducing the Student's Anxiety}

It is generally believed that anxiety refers to a state that an individual cannot realize his anticipation or be threatened by the barriers which cannot be overcome, causing a frustration to their self-esteem and self-confidence, or generating a sense of failure and guilt. In the second language learning, linguists and education experts have classified anxiety into different categories. Duly divided foreign language learning anxiety into state anxiety and personality anxiety; Scovel has classified it into facilitative anxiety and obstructive anxiety; Horvitz has classified foreign language learning anxiety into communicative anxiety, examining anxiety and negative evaluation anxiety, and Chinese students' English learning anxiety are mainly classroom anxiety, examining anxiety and negative evaluation anxiety. In a learning process containing simple tasks, a certain degree of anxiety is helpful for students to concentrate on their study. Such as in listening class, the teacher may ask the students to concentrate on the listening materials, then the students' appropriate anxiety can help them to become more serious and invest their energy into the listening content, thus obtaining a better learning effect. But when confronting complex tasks, anxiety is of no use in helping the students' study. According to the results of a survey conducted by the author, there are $76.2 \%$ of college students have classroom anxiety, $75.8 \%$ of the students have the examining anxiety, and $71.2 \%$ of the students have negative evaluation anxiety. Anxiety may cause the learning burnout of the students; teachers should minimize the level of students' anxiety and maximize the effect of language input. For classroom anxiety, the teachers should try to create a harmonious and relaxed learning environment for the students, meanwhile, the teachers should consider the difficulty of the teaching materials and the questions proposed by them. They should control the difficulty of teaching materials and guide the students step by step, letting the students enjoy the successful experience. A group communication can also reduce the anxiety of college students. Examining anxiety stems from the failure of the past, after the setbacks in the examinations, the students tend to be extremely upset before the exams. When facing this kind of situation, the teachers need to guide and help the students, "the purpose of learning English is not only for exams, but also for communication." Secondly, in the daily teaching process, the teachers should help students to encourage themselves to build their own confidence and reduce the psychological impact of the failure of the past. Students are afraid of the teachers' negative evaluation on them and being laughed at by their classmates, therefore, the teachers should be aware of their language in the classroom and respect students. When giving comments to the students, they should make comprehensive evaluations on them but not just according to their academic performance. In addition, the mutual respect between students should be emphasized. Group communication, relaxation before examination, encouragement from others could help to reduce the learners' anxiety and psychological inhibition.

\subsection{From the Teachers' Perspective}

Teachers' emotion has a remarkable effect on student's learning attitude, learning interest and learning motivation. Teachers should be the daily role model for the students; the teachers can help students to reduce their anxiety mainly from the following aspects: their professional knowledge, the harmonious relationship with the students, teaching methods and classroom atmosphere. Thus they can stimulate students' English learning motivation and optimize the college English teaching effect.

\subsubsection{Enriching the Professional Skills}

Emotion has the nature of migration. The students' feeling and impression of the teachers can be migrated into the teaching content. Teachers with professional knowledge and wide range of skills can lead students to study better and faster, and it is also a major premise of mutual trust between the teachers and students. Therefore every English teacher should analyze themselves and understand their own characteristics, everyone has his own advantages and disadvantages, when teachers get to know themselves, they can maximize their own advantages in the classroom; for their own weaknesses, they could ask the experienced colleagues constantly so as to improve their own knowledge structure and their professional quality. In addition to overcoming their own defects, teachers who are popular with the students must be good at studying. In the ever-changing era, knowledge is always updating in a fast pace, teachers who are good at learning could show the latest professional knowledge to the students, making students appreciate the charm of knowledge. By doing this, the teachers can not only improve the professional ability, but also establish an image of authority in front of the students. But only abundant professional knowledge is not enough for teachers, English is a kind of communicative tool, teachers should have the ability to analyze the complicated knowledge and show it in a simple form to the students. Some English teachers do possess excellent professional 
ability, but their teaching effect is not ideal. Because their teaching approach do not meet the demand of students, and the students can't adjust to the teaching process. Teachers should make the effective interpretation on teaching materials. First of all, they should prepare their classes carefully before class and analyze the teaching materials seriously; second, organizing the teaching process scientifically, the teachers should let students to participate in the classroom communication and interaction by communicative teaching methods such as asking questions, doing practice and making dialogues so as to organize the classroom teaching effectively; Also, the teachers need to write a summary after class to summarize the advantages and disadvantages of their last class and find a way of avoiding repeated mistakes.

\subsubsection{Establishing a Harmonious Relationship between Teachers and Students}

What the students are pursuing for is the relationship of equality between teachers and them, which is mutually dependent on each other. From the current situation of English teaching, the relationship between teachers and students belongs to "transmitter" and "receiver" and knowledge is still the only link between teachers and students. A good relationship between teachers and students is the premise of the teaching activities, and it can greatly affect the learning effect of the students. The teachers should make continuous efforts to establish a

Rogers once put forward that: "The keys to promote teaching are not teaching skills, nor the audio-visual equipment, books and materials, but lies in the quality of the relationship between teachers and students." The relationship between teachers and students depends largely on whether the teachers love or respect the student. College students' are eager to get the affirmation and respect from the teachers, they want to gain them with their own efforts; similarly, students of poor grades also hope to be able to hear the teachers' encouragement and praise. Therefore the teachers should consider the feelings of students, using incentive words to stimulate the students' learning motivation. In conclusion, teachers must treat the students with sincerity and communicate with students initiatively. They should respect students' personality and protect students' self-esteem, creating a fair and enjoyable language learning environment for students.

\section{Conclusion}

English teaching plays a very important role in higher education in China. Affective teaching, as an effective way to optimize the teaching effect, is drawing increasing attention and gradually becoming an important research topic in the field of language and education research. Based on the related theory of emotional factors, humanistic teaching theory and the theory of Krashen's affective filter hypothesis, the author finds that emotional factors have a profound impact on English teaching in colleges in China, but the attitude of most students in colleges towards English study is negative and passive. Therefore, it is necessary to adopt flexible and effective measures to solve the existing problems in current college English learning.

If the teachers can learn more about the students and increase the time of communicating with the students to establish a good classroom atmosphere for them, then the teaching effect will be highly optimized; if the teachers can apply positive emotions to the teaching materials and teaching organization when they are teaching the second language knowledge, then the students' learning motivation and learning enthusiasm will be stimulated to the greatest extent.

\section{References}

Arnold, J. \& Brown, H. Douglas. (1999). Affect in Language Learning. Cambridge: Cambridge university press.

Brown, H. D. (1994). Teaching by Principles. Englewood Cliff, NJ: Prentice Hall.

Brown, H.D. (1977). Teaching by Principles: Interactive Language Teaching Methodology. New York: Principles Hall Regents.

Bruner, J. (1962). The Culture of Education. Cambridge, MA: Harvard University Press.

Cesario, Joseph, Grant, Heidi, Higgins, E. Tory. (2004). Regulatory Fit and Persuasion: Transfer from "Feeling Right". Journal of Personality \& Social Psychology, Mar, Vol. 86, Issue 3. http://dx.doi.org/10.1037/0022-3514.86.3.388

Chomsky, N. (1988). Language and Problems of Knowledge. Cambridge, MA: MIT Press.

Dornyei, Z. (2001). Motivational Strategies in the Language Classroom. Cambridge: Cambridge University Press. http://dx.doi.org/10.1017/CBO9780511667343

Ellis, R. (1994). Understanding Second Language Acquisition . Oxford: OUP.

Hedge, T. (2002). Teaching and Learning in the Language Classroom. Oxford: Oxford University Press, p.17-24. 
Johnson, K. (2002). An Introduction to Foreign Language Learning and Teaching. Beijing: Foreign Language Teaching and Research Press.

Krashen. (1985). The Input Hypothesis: Issues and Implications. London: Longman.

Liu Runqing. (1999). On English Language Teaching. Beijing: Foreign Language Teaching and Research Press.

Michael Welker. (1999). We live deeper than we thinker: the genius of Schleiermacher's earliest ethics. Theology Today, July, Vo1.56. http://dx.doi.org/10.1177/004057369905600204

Neumann, Roland, Seibt, Beate, Strack, Fritz. (2001). The influence of mood on the intensity of emotional responses: Disentangling feeling and knowing. Cognition \& Emotion, Nov, Vol. 15, Issue 6. http://dx.doi.org/10.1080/02699930143000266

Richard McCarty. (1993). Kantian moral motivation and the feeling of respect. Journal of the History Philosophy, July, Vo1.31, Issue. 3. http://dx.doi.org/10.1353/hph.1993.0050

Richards, J\&C. Lockhart. (1996). Reflective Teaching in Second Language Classroom. Cambridge: Cambridge University Press.

Robinson, Michael D, Clore, Gerald L. (2002). Belief and Feeling: Evidence for an Accessibility Model of Emotional Self-Report. Psychological Bulletin, Nov, Vol. 128, Issue 6. http://dx.doi.org/10.1037//0033-2909.128.6.934

Schlenker, Barry R. Wowra, Scott A. (2003). Carryover Effects of Feeling Socially Transparent or Impenetrable on Strategic Self-Presentation. Journal of Personality \& Social Psychology, Nov, Vol.85, Issue 5. http://dx.doi.org/10.1037/0022-3514.85.5.871

Stem, H. H. (1983). Fundamental Concepts of Language Teaching. Oxford: OUP.

Stephen D. Krashen. (1982). Principles of Practice in Second Language Acquisition. Oxford: Pergamon Press.

Ulla H, Graneheim, Ulf Isaksson, Inga-Maj Persson Ljung, Lilian Jansson. (2005). Balancing between contradictions: the meaning of interaction with people suffering from dementia and "behavioral disturbances". International Journal of Aging \& Human Development, Feb Vol.60, Issue 2.

Wang Qimin. (2003). Analysis on the Factors Restraining College English Learning Effect. Foreign Language World., Vol:(2). 